\title{
Relationship of APP mRNA Transcripts and Levels of NGF and Low-Affinity NGF Receptors to Behavioral Measures of Age-related Cognitive Dysfunction
}

\author{
Mark D. Lindner, ${ }^{1}$ Steven I. Dworetzky, ${ }^{2}$ Craig Sampson, ${ }^{2}$ and Rebekah Loy ${ }^{1,3}$ \\ University of Rochester School of Medicine and Dentistry Neurogerontology Unit, Monroe Community Hospital \\ Rochester, New York 14620, "Bristol-Myers Squibb Pharmaceutical Research Institute, Department of Biophysics and \\ Molecular Biology, Wallingford, Connecticut 06492, and Batavia V.A. Medical Center, Batavia, New York 14020
}

This study was designed to examine the relationship between cognitive function and endogenous levels of NGF, low-affinity NGF receptor (LNGFR), and amyloid precursor protein (APP) mRNAs. Using 3 month $(n=5), 18$ month $(n=$ $40)$, and 29 month $(n=17)$ Fischer- 344 male rats, cognitive function was assessed with the Morris water maze, reverse transcription and polymerase chain reaction were used to quantify APP mRNAs, and NGF and LNGFR levels were determined with an ELISA.

Cognitive function declined progressively with age from 3 months to 18 months, and from 18 months to 29 months, but only RNA content in the tissue declined significantly from 3 months to 18 months. Between 18 month and 29 month rats there were small but statistically significant decreases only for Kunitz protease inhibitor (KPI)-inclusive mRNAs and cortical NGF levels. There was a small but statistically significant correlation between cognitive function and \% KPI (the amount of KPI APP mRNAs relative to the total amount of APP mRNA), with lower \% KPI related to more impaired spatial learning. No other statistically significant correlation or linear relationship could be detected between cognitive function and any of the other neurological measures or any combination of these measures (i.e., hippocampal levels of APP 695 mRNA, cortical and hippocampal levels of NGF, and cortical, hippocampal, and basal forebrain levels of LNGFR).

Although there were no strong linear relationships between cognitive function and our neurological measures, a post hoc exploratory cluster analysis suggests that there may be a brief transient increase in tissue levels of \% $\mathrm{KPI}$, NGF, and LNGFR during the initial period of cognitive deterioration before substantial neuronal degeneration has occurred. To test this possibility, levels of these substances in the tissue, and the number of remaining neurons in which

\footnotetext{
Received June 25, 1993; revised Sept. 8, 1993; accepted Oct. 4, 1993

We thank Judy Miller for conducting the ELISA assays, Nelly Masias at BristolMyers Squibb Department of Data Processing for customizing the San Diego Instruments Morris water maze program, and Howard Mosher and Lynn Keller at Bristol-Myers Squibb Department of Veterinary Sciences for caring for the aged rat colony. The following reagents were generously provided: GAM and IG3 antimouse NGF antibodies (K. Crutcher), NGF (W. Mobley), anti-Rex and Rex (G. Weskamp), and 192-IgG (P. DiStefano). The behavioral data presented in this study were collected by M.D.L. while at Bristol-Myers Squibb Pharmaceutical Research Institute. This work was supported by AG09231.

Correspondence should be addressed to Mark D. Lindner. Ph.D., CytoTherapeutics, Two Richmond Square, Providence, RI 02906.

Copyright $(\vec{c}) 1994$ Socicty for Neuroscience $0270-64 / 4 / 94 / 142282-08 \$ 05.00 / 0$
}

they are being produced will need to be measured independently.

IKey words: NGF, low-affinity NGF receptor, amyloid precursor protein mRNA, polymerase chain reaction, ELISA, Morris water maze, aging]

Two biological measures closely associated with the progression of Alzheimer's dementia are the increased density of senile plaques (Roth et al., 1966; Blessed et al., 1968), and the atrophy/ degeneration of cholinergic basal forebrain neurons (Whitehouse et al., 1981; McGeer et al., 1984) that have low-affinity receptors for NGF (LNGFR) (Kordower et al., 1989; Mufson and Kordower, 1989; Mufson et al., 1989a; Loy et al., 1990). The dementia-related loss of LNGFR-positive neurons is greatcst in the posterior basal forebrain, which projects to the hippocampus and cortex (Higgins and Mufson, 1989; Mufson et al., 1989b), and reduced NGF levels in those target tissues may play a causal role in cholinergic/LNGFR neuronal degeneration and dementia (Appcl, 1981). Amyloid is the central constituent of senile plaques, and plaques may form as a consequence of either an overproduction and/or aberrant metabolism of the amyloid precursor protein (APP) (Robakis et al., 1991), or as a consequence of differential expression of APP mRNA transcripts (Harrison et al., 1991). Results consistent with both of these possibilities have been reported in Alzheimer's patients (Jacobsen et al., 1991; Tanaka et al., 1992).

Experimental manipulations of APP and NGF also suggest that endogenous levels of these substances may be interrelated. NGF alters the ratios of APP mRNAs during neuronal differentiation of PC12 cells such that the level of APP 770 mRNA is reduced and the level of APP $695 \mathrm{mRNA}$ is increascd (Smith et al., 1991). Both NGF and low concentrations of APP increase neurite length and branching in PC12 cells, and antibodies to APP 695 block the neurite-promoting effects of NGF (Milward et al., 1992). The neurotoxic carboxy-terminal fragment of amyloid binds specifically and with high affinity to NGF-treated PC12 cells (Kozlowski et al., 1992), and NGF potentiates the neurotoxicity of amyloid (Yankner el al, 1990).

Consistent with results from clinical studies of Alzheimer's disease, both degeneration of LNGFR-positive neurons in the basal forebrain (Koh et al., 1989; Fischer et al., 1992) and altered levels and transcript ratios of APP mRNA (Higgins et al., 1990; Greenc et al., 1992) have been observed in aged rats with cognitive deficits (impaired performance in spatial learning tasks). Although it remains to be determined how valid aged and learn- 
ing-impaired rats are as a model of Alzheimer's disease, for the present this seems to be the best rodent model available. Therefore, the purpose of the present study was to determine whether endogenous levels of NGF and LNGFR in the basal forebrain, cortex, and hippocampus, or hippocampal levels of APP mRNA transcripts are closely related to behavioral measures of agerelated cognitive deficits.

\section{Materials and Methods}

Animals. Male Fischer-344 rats from Harlan Sprague-Dawley were acclimated to the colony room for more than $30 \mathrm{~d}$ before behavioral testing began, at which time they were aged 18 months $(n=40)$, and 29 months $(n=17)$. A small group of young 3 month rats $(n=5)$ was included to provide a reference point. Rats were group housed in stainless steel cages with wire-mesh floors, and food and water were available ad libitum.

Morris water maze. The Morris water maze, a black 152-cm-diameter pool filled to a depth of $35 \mathrm{~cm}$ with $21^{\circ} \mathrm{C}$ water, containing a small 10 $\mathrm{cm}^{2}$ platform submerged $1.2 \mathrm{~cm}$ below the surface of the water, was located in a temperature-controlled $22^{\circ} \mathrm{C}$ room. There were large highcontrast visual cues throughout the room. Tracking and computation of dependent measures were performed by an automated water maze system (San Diego Instruments, San Diego, CA). Swim distance, the length of the path that the animal swims to find the platform, is the most appropriate measure of performance in this task (Morris, 1984; Lindner and Gribkoff, 1991; Lindner et al., 1992), and it was used as the dependent measure. In order to remove the influence of swim speed on swim distance in trials where the platform was not located during the $2 \mathrm{~min}$ time limit, a maximum swim distance of $36 \mathrm{~m}$ (the median swim distance on all trials where the platform was not located) was assigned on all such trials and on trials where rats located the platform within the 2 min time limit but swam more than $36 \mathrm{~m}$ (Lindner et al., 1992).

Each rat received the same sequence of random starting positions and initial directions. Trials were a maximum of $120 \mathrm{sec}$ in duration, and rats remained on the platform for $20 \mathrm{sec}$ at the end of cach trial. In order to prevent hypothermia, rats were placed in a $38.5^{\circ} \mathrm{C}$ warm-water bath during the $20 \mathrm{~min}$ intertrial interval and placed under an infrared heat lamp for 15 min after the second trial of the day, before being returned to their home cages (Lindner and Gribkoff, 1991). During acquisition training all rats received two trials each day for $10 \mathrm{~d}$ with the platform located in the same position. The platform was removed from the pool for a single $120 \mathrm{sec}$ probe trial conducted the day following acquisition training. During the probe trial, the following measures were recorded: (1) the number of platform annulus crossings, (2) the proximity ratio (the proportion of the swim distance within an annulus surrounding the platform which included $25 \%$ of the surface area of the pool), and (3) the degree of thigmotaxia (Lindner and Schallert, 1988) (the proportion of the swim distance in which the rat was in contact with the wall of the pool). On the day following the probe trial, swim distance was recorded during two "cued" trials in which the platform was moved randomly to different locations while marked with a large $\left(250 \mathrm{~cm}^{2}\right)$ visual cue.

Tissue dissection. Within $10 \mathrm{~d}$ after the end of behavioral testing, rats were decapitated and within $5 \mathrm{~min}$ the septum and vertical limb of the diagonal band [VDB; between $1.7 \mathrm{~mm}$ anterior and $0.3 \mathrm{~mm}$ posterior to bregma (Paxinos and Watson, 1986), caudal to the genu of the corpus callosum, and medial to the lateral ventricles], both hippocampi, and a large piece of neocortex that included the frontal (from $0.3 \mathrm{~mm}$ posterior to bregma), temporal, parietal, and occipital lobes of the right hemisphere, were dissected on ice, quick frozen in liquid nitrogen, and stored at $-70^{\circ} \mathrm{C}$.

Reverse transcription and PCR. Reverse transcription (RT) and polymerase chain reaction (PCR) wcrc uscd to quantify mRNA levels of APP 695,751 , and 770 in the right hippocampus, based on the methods of Gilliland et al. (1990). The oligonucleotide primers were sense (5'TGCCACCACTACCACAACTACCACTGAGTC-3') and antisense (5'CCTCTCTTTGGCTTTCTGGAAATGGG-3'). The PCR technique was used to delete 25 nucleotides from the APP 695 isoform, which was subcloned into the TA cloning vector (In-Vitrogen). This internal standard utilized the same primers required for the APP isoforms and resulted in a smaller PCR product.

Hippocampal tissue was homogenized and the RNA was isolated according to Chomczynski and Sacchi (1987). All RNA samples were quantified by UV spectrophotometry and stored at $-70^{\circ} \mathrm{C}$. RNA $(2 \mu \mathrm{g})$ was used for each RT. The final concentrations of the components in the RT mixture were $20 \mathrm{U}$ of RNasin (Promega), $1 \mathrm{~mm}$ dNTPs (Pharmacia), 100 pmol of random hexamer (In-Vitrogen), $1.5 \mathrm{~mm} \mathrm{MgCl}_{2}$, $100 \mathrm{~mm}$ Tris-Cl, pH 8.3, $50 \mathrm{~mm} \mathrm{KCl}$, and $400 \mathrm{U}$ of Moloney virus reverse transcriptase (GIBCO-Bethesda Research Labs). After addition of each component the reactions were incubated at room temperature for $10 \mathrm{~min}, 42^{\circ} \mathrm{C}$ for $60 \mathrm{~min}$, followed by inactivation at $94^{\circ} \mathrm{C}$ for 10 min. Lach RT reaction containcd cnough samplc for 10 scparate amplifications of the APP isoforms, that is, $10 \mu \mathrm{l}$ for each PCR amplification. Each PCR reaction mix contained $0.2 \mathrm{~mm}$ dNTPs (from RT reaction), $10 \mathrm{~mm}$ Tris-Cl, pH $8.3,50 \mathrm{~mm} \mathrm{KCl}, 2.5 \mathrm{~mm} \mathrm{MgCl}_{2}, 100$ pmol of each oligonucleotide primer [exons 6 and 9 of the rat APP gene, which span the Kunitz protease inhibitor (KPI) and OX-2 domains], $2.5 \mathrm{U}$ of amplitaq polymerase (Perkin-Elmer), $5 \mu \mathrm{Ci}$ of ${ }^{32} \mathrm{P}-\mathrm{dCTP}$, and the internal DNA standards ranging from 1 attogram up to 100 attograms. The PCR parameters were $94^{\circ} \mathrm{C}$ for $45 \mathrm{sec}, 60^{\circ} \mathrm{C}$ for $90 \mathrm{sec}$, and $72^{\circ} \mathrm{C}$ for $120 \mathrm{sec}$ at 25 cycles followed by a $7 \mathrm{~min} 72^{\circ} \mathrm{C}$ extension period. Amplified product $(15 \mu \mathrm{l})$ was separated on a $6 \%$ native polyacrylamide gel. The gel was vacuum dried and analyzed on an AMBIS radioanalytical imaging system. Standard curves were prepared from the known amount of internal standard DNA added to each tube and the cpms wcre detccted by radioanalytical imaging.

NGF ELISA. NGF levels in the left hippocampus and the right cortex, and NGF receptor levels in the left hippocampus, the cortex, and the VDB were determined with two-site enzyme-linked immunosorbent assays (ELISA; adapted from Weskamp and Otten, 1987; Mobley et al., 1989; Lindner et al., 1993). Immunoplates (Nunc, Maxisorb F96) were coated with $100 \mu \mathrm{l}$ of goat anti-mouse NGF polyclonal antibody (GAM; $20 \mu \mathrm{g} / \mathrm{ml})$ in coating buffer $\left(3.07 \mathrm{~mm} \mathrm{NaN}_{3}, 34.88 \mathrm{~mm} \mathrm{NaHCO}_{3}, 16.13\right.$ $\mathrm{mM} \mathrm{Na}_{2} \mathrm{CO}_{3}, \mathrm{pH} 9.6$ ), and incubated overnight at $4^{\circ} \mathrm{C}$. The GAM solution was removed, and the plates washed with washing buffer $(10 \mathrm{~mm}$ PBS, pH 7.4, and $0.05 \%$ Tween 20 ), incubated at room temperature for $1 \mathrm{hr}$ with $200 \mu \mathrm{l}$ of blocking buffer [ $5 \%$ fetal calf serum (FCS) in PBS], and then washed three times with washing buffer.

Samples were prepared by homogenizing frozen tissues with a handheld Polytron PT 1200 (Kinematica, AG) for $20 \mathrm{sec}$ in 1:10 (w/v) sample buffer $[0.5 \% \mathrm{BSA}$, aprotinin $(20 \mathrm{KIU} / \mathrm{ml}$; Sigma), $0.0987 \mathrm{~mm}$ phenylmethylsulfonyl fluoride, and $0.0982 \mathrm{~mm}$ benzethonium chloride in PBS] and centrifuged for $30 \mathrm{~min}$ at $15,000 \times \mathrm{g}$ at $4^{\circ} \mathrm{C}$, and then Tween 20 (final concentration of $0.05 \%$ ) was added to the supernatant. For each brain area, tissues for all subjects were included in a single assay, and one standard curve was used for all samples. Half of each homogenate was used in the NGF receptor assay below. NGF, purified from mouse submaxillary gland (Mobley et al., 1986), was serially diluted to produce a standard curve with concentrations of $0-100 \mathrm{pg} / 100 \mu \mathrm{l}$. Standards and sample solutions were each added to four replicate wells and were left on the plate overnight at $4^{\circ} \mathrm{C}$. (Preliminary studies showed no binding to wells coated with normal rabbit serum, so these controls were omitted from this assay and the LNGFR assays described below.) The plates were washed with PBS.

Wells were coated with $100 \mu$ of rabbit anti-mouse NGF monoclonal antibody (IG3, $0.012 \mathrm{mg} / \mathrm{ml}$ ) in $1 \%$ FCS, $0.1 \%$ Tween 20 , and PBS, and the plates were incubated overnight at $4^{\circ} \mathrm{C}$. After the plates were washed with PBS, $100 \mu$ l of biotinylated goat anti-rabbit antibody (Vector; $0.3 \mu \mathrm{g} / \mathrm{ml}$ in PBS containing $1 \%$ FCS and $0.1 \%$ Tween 20 ) was added to each well, and the plate incubated overnight at $4^{\circ} \mathrm{C}$. Plates were then washed three times in PBS, and incubated for $2 \mathrm{hr}$ at room temperature with $100 \mu$ l of HRP-streptavidin (Zymed; 1:2000 in PBS containing $1 \%$ FCS). Plates were then washed three times with PBS, and developed with $100 \mu \mathrm{l} /$ well of a freshly made solution containing $0.04 \% O$-phenylenediamine and $0.012 \%$ hydrogen peroxide in a phosphate-citrate buffer, $\mathrm{pH} 5.0$, by incubating the foil-covered plates for $20 \mathrm{~min}$ at room temperature. The plates were lightly agitated during all incubations in both NGF and LNGFR assays, and the reactions of both assays were stopped by adding $50 \mu \mathrm{l}$ of $2.5 \mathrm{M} \mathrm{H}_{2} \mathrm{SO}_{4}$ to each well. Optical densities were measured with an MR 600 Microplate Reader (Dynatech Laboratories, Inc.) using a 490 nm filter and a 590 nm reference filter. Least-squares regression analysis was performed with SIGMAPLOT 5.01 (Jandel) to determine the parameters of a four-parameter logistic log function (Rodbard and McClean, 1977; Plikaytis et al., 1991) for the standard curve.

$N G F$ receptor ELISA. The ELISA for LNGFR used the same incubation and wash times and procedures as the NGF ELISA except for 
the following. Plates were initially coated with $100 \mu \mathrm{l}$ of anti-Rex at a concentration of $1 \mu \mathrm{g} / \mathrm{ml}$ in PBS ( $20 \mathrm{~mm}$ phosphate-buffered saline, $\mathrm{pH}$ 8.0). Tween $20(0.05 \%$ in PBS) was used as the washing buffer. The blocking buffer was $200 \mu \mathrm{l}$ of $0.25 \% \mathrm{BSA}, 7.69 \mathrm{~mm}$ sodium azide, 0.9 mM EDTA, $1 \%$ normal horse serum (NHS), and $0.05 \%$ Tween 20 in borate-buffered saline, $\mathrm{pH}$ 8.5. Sample homogenates from the NGF FIISA protocol above, and Rex [the ectodomain of the rat p75 NGF receptor (Weskamp and Reichardt, 1991)] serially diluted to produce a standard curve with concentrations from 0 to $100 \mathrm{pg} / 100 \mu \mathrm{l}$, were each added to four replicate wells and incubated for $3 \mathrm{hr}$. A different blocking buffer was used in the second blocking step: $200 \mu \mathrm{l}$ of $0.05 \%$ Tween 20 , $1 \%$ NHS, and $0.01 \%$ horse anti-mouse antibody (HAM) in PBS. The plates were washed and loaded $100 \mu \mathrm{l} /$ well with $8.97 \mu \mathrm{g} / \mathrm{ml}$ of $192-\mathrm{IgG}$ in PBS. Plates were washed with $100 \mu \mathrm{l}$ biotinylated HAM (Vector; $0.15 \mu \mathrm{g} / \mathrm{ml}$ in PBS containing $1 \%$ NHS). Tween $20(0.1 \%)$ was added to each well and plates were incubated $1 \mathrm{hr}$ at room temperature. Plates were washed six times with washing buffer and incubated for $2 \mathrm{hr}$ at room temperature with $100 \mu \mathrm{l} \mathrm{HRP-streptavidin} \mathrm{(Zymed;} \mathrm{1:2000} \mathrm{in}$ PBS containing $1 \%$ NHS).

Data analysis. The data were analyzed with SAS procedures for general linear models, with options for repeated-measures where appropriate, and Cronbach's coefficient alpha was computed to determine reliability (SAS Institute Inc., 1989). $\omega^{2}$ was computed as a measure of effect size (Dodd and Schultz, 1973). Planned contrasts were conducted for differences between 3 month and 18 month rats, and between 18 month and 29 month rats. A post hoc cluster analysis was conducted using the SAS procedure PROC FASTCLUS (SAS Institute Inc., 1989). Data are presented in the text and in all figures as means and standard errors of the mean.

\section{Results}

Morris waler maze

All rats began swimming within a few seconds after first entering the water, and were able to keep their heads above water and swim throughout the pool without apparent difficulty. Subjects could be very reliably distinguished from one another in terms of swim speed (Cronbach's reliability coefficient, $r=0.917$ ), and age accounted for a large proportion of the variance in swim speeds $\left(\omega^{2}=0.65\right)$. Swim speeds were $0.39 \pm 0.007,0.33 \pm$ 0.004 , and $0.29 \pm 0.005 \mathrm{~m} / \mathrm{sec}$ for the 3,18 , and 29 month rats, respectively; this represented a statistically significant difference $[F(2,59)=57.67, p=0.0001]$.

Acquisition. On the first day of acquisition training, all age groups had long swim distances of approximately $24 \mathrm{~m}$, which were not significantly different from each other $[F(2,59)=0.43$, $p=0.65]$. Over the $10 \mathrm{~d}$ of acquisition training, all groups showed evidence of improvement; the main effect of days was statistically significant $[F(9,531)=15.02, p=0.0001]$ (Fig. $1 A$ ). Younger rats performed better than older rats; the main effect of age was statistically significant $[F(2,59)=8.87, p=0.0004]$. In addition, 18 month rats were impaired relative to 3 month rats $[F(1,59)=9.13, p=0.004]$, and 29 month rats were impaired relative to 18 month rats $[F(1,59)=5.45, p=0.02$. The total proportion of variance accounted for by age $\left[\omega^{2}\right.$ values for age $(0.253)$, plus the age $\times$ days interaction $(0.029)]=0.282$.

Probe trial. There was a significant difference between the groups in terms of the number of annulus crossings (the number of times the previous platform location was crossed over) $[F(2,59)$ $=6.23, p=0.0035$ ] (Fig. $1 B$ ). The 18 month rats had fewer annulus crossings than the 3 month rats $[F(1,59)=5.21, p=$ 0.026 ], and 29 month rats had fewer annulus crossings than 18 month rats $[F(1,59)=4.99, p=0.03]$. There were also significant differences between the groups in terms of the proportion of their swim path near the previous platform location (proximity ratio) $[F(2,59)=24.11, p=0.0001]$ (Fig. $1 B)$. The 18 month rats had smaller proximity ratios than 3 month rats $[F(1,59)=$ $22.41, p=0.0001$ ], and 29 month rats had smaller proximity ratios than 18 month rats $[F(1,59)=17.09, p=0.0001]$. Finally, the groups were significantly different in terms of the measure of thigmotaxia [i.e., the proportion of their swim path in which their snout or whiskers were in contact with the wall of the pool (Lindner and Schallert, 1988) $[F(2,59)=3.06, p=0.05]$ (Fig. $1 B)$. The measure of thigmotaxia was not significantly higher in 18 month rats than in 3 month rats $[F(1,59)=0.37, p=$ $0.54]$, but 29 month rats did have significantly higher measures of thigmotaxia than 18 month rats $[F(1,59)=5.05, p=0.03]$.

Overall performance in the probe trial, represented by the combination of standardized values of annulus crossings, proximity ratios, and degree of thigmotaxia, showed that there was a significant main effect for age $[F(2,59)=12.34, p=0.0001$; $\left.\omega^{2}=0.268\right]$. The 18 month rats were impaired relative to 3 month rats $[F(1,59)=8.51, p=0.005]$, and 29 month rats were impaired relative to 18 month rats $[F(1,59)=11.71, p=0.001]$. Acquisition swim distances were correlated with performance in the probe trial $[r(62)=-0.48, p=0.0001]$.

Cued platform. There were no significant differences between groups in terms of their swim distance to the cued platform $[F(2,59)=2.95, p=0.06]$ (Fig. $1 A$ ). Fisher's $Z$ transformations (Fisher, 1934) show that the effect for age was substantially larger during maze acquisition ( $\omega^{2}=0.282$ ) and during the single probe trial $\left(\omega^{2}=0.268\right)$ than in the cued platform task $\left(\omega^{2}=0.055 ; p\right.$ values $<0.05)$.

\section{$A P P M R N_{A}$}

$A P P m R N A / \mu g$ total $R N A$. The three amplified DNA products corresponding to the APP transcripts were easily visualized after separation by PAGE, and all three forms were clearly noted to be present in all samples. APP 695 mRNA made up $97.4 \%$ of all APP mRNA, and the groups were not different with respect to their levels of APP 695 mRNA $[F(2,59)=1.70, p=0.19]$ (Fig. 2A). The levels of APP 695 mRNA were not significantly different between 3 month and 18 month rats $[F(1,59)=1.19$, $p=0.28]$, or between 18 month and 29 month rats $[F(1,59)=$ $2.77, p=0.11$; power $=0.90]$. APP 751 mRNA represented $2 \%$ of all APP mRNA, and 29 month rats had significantly less APP 751 mRNA than 18 month rats $[F(1,59)=4.56, p=0.04]$ (Fig. $2 A$ ), but there was no significant difference between 3 month and 18 month rats $[F(1,59)=0.41, p=0.53]$. APP 770 mRNA represented only $0.6 \%$ of all APP mRNA, and 29 month rats had significantly less APP 770 mRNA than 18 month rats $[F(1,59)=5.81, p=0.02]$ (Fig. $2 A$ ), but there was no significant difference between 3 month and 18 month rats $[F(1,59)=0.71$, $p=0.41]$.

APP $m R N A / m g$ tissue. The right hippocampi weighed an average of $82.6 \mathrm{mg}$, and the groups were not different with respect to hippocampal weights $[F(2,59)=1.40, p=0.25]$. However, the amount of RNA recovered per milligram of tissue did decline with age $[F(2,59)=9.95, p=0.0002]$. Contrasts showed that the $36 \%$ decrease in total RNA content from $0.89 \pm 0.07$ to $0.57 \pm 0.02 \mu \mathrm{g} / \mathrm{mg}$ tissue for the 3 month and 18 month rats, respectively, was significant $[F(1,59)=19.67, p=0.0001]$, but at $0.62 \pm 0.04 \mu \mathrm{g} / \mathrm{mg}$ tissue the 29 month rats did not have any less RNA than 18 month rats $[F(1,59)=1.63, p=0.21]$.

The effects of age on APP mRNA levels in hippocampal tissue were the same as the effects of age on APP mRNA levels with respect to total RNA presented above. Rats (29 months) did not have significantly lower APP 695 mRNA levels than 18 month rats $[F(1,59)=1.86, p=0.18]$, but 29 month rats had significantly less of both APP $751 \mathrm{mRNA}[F(1,59)=3.71, p=$ 
A.

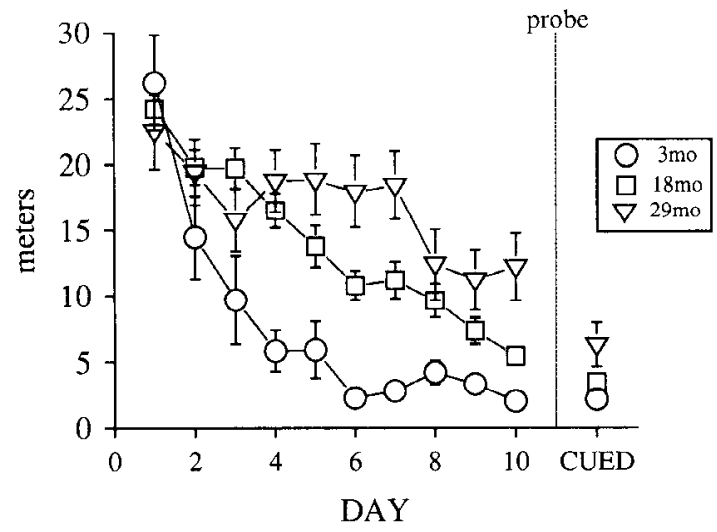

B.

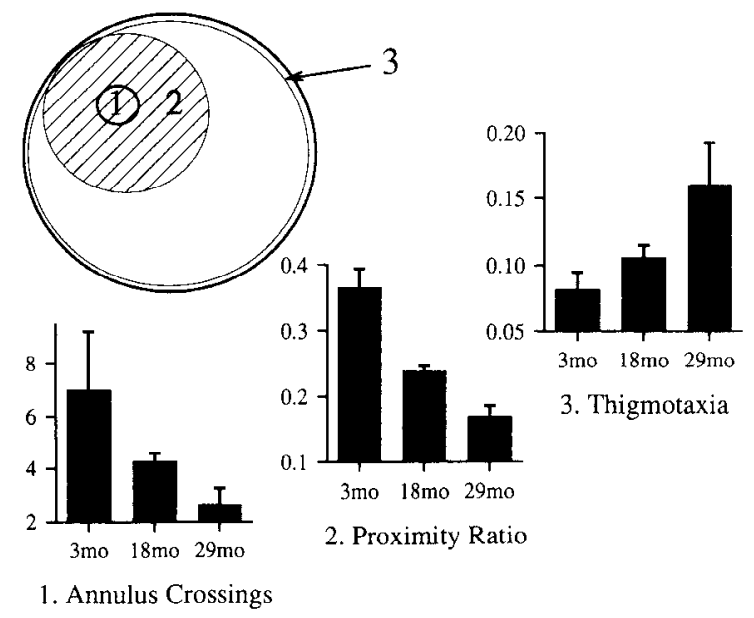

Figure 1. Morris water maze data. A, Swim distance during acquisition training and during final "cued" trials (note that time of probe trial is indicated with vertical dashed line). $B$, Swim performance during probe trial (platform removed). 1 , number of annulus crossings; 2 , proportion of swim path near previous platform location; 3, proportion of swim path in contact with wall of pool.

$0.05]$ and APP 770 mRNA $[; F(1,59)=4.96, p=0.03]$ than 18 month rats (Fig. $2 B$ ).

$\% K P I$. In order to be consistent with previous studies and in order to determine whether the levels of KPI-inclusive forms of APP mRNA were actually reduced relative to the levels of total APP mRNA, the ratios of KPI-inclusive APP mRNA levels to total APP mRNA levels were analyzed. The ratio of KPIcontaining forms of APP mRNA (751 and 770) relative to the total amount of APP mRNA (\%KPI) was significantly different with respect to age $[F(2,59)=5.02, p=0.01]$. While 3 month rats did not differ from 18 month rats with respect to the \%KPI $[F(1,59)=0.70, p=0.41], 29$ month rats had a significantly smaller \%KPI than 18 month rats $[F(1,59)=8.14, p=0.007]$ (Fig. 2C).

\section{$N G F / L N G F R$ levels}

NGF and LNGFR levels for each age group, in $\mathrm{pg} / \mathrm{mg}$ tissue, are presented for the different brain areas in Table 1. Cortical NGF levels were not different between 3 month and 18 month rats $\left[F(1,59)=1.29, p=0.26 ; \omega^{2}=0.0044\right]$, but NGF levels in the cortex were significantly higher in the 18 month rats than in the 29 month rats $[F(1,59)=5.70, p=0.02]$. Although this effect was statistically significant, the magnitude of the effect was relatively small $\left(\omega^{2}=0.071\right)$. No statistically significant
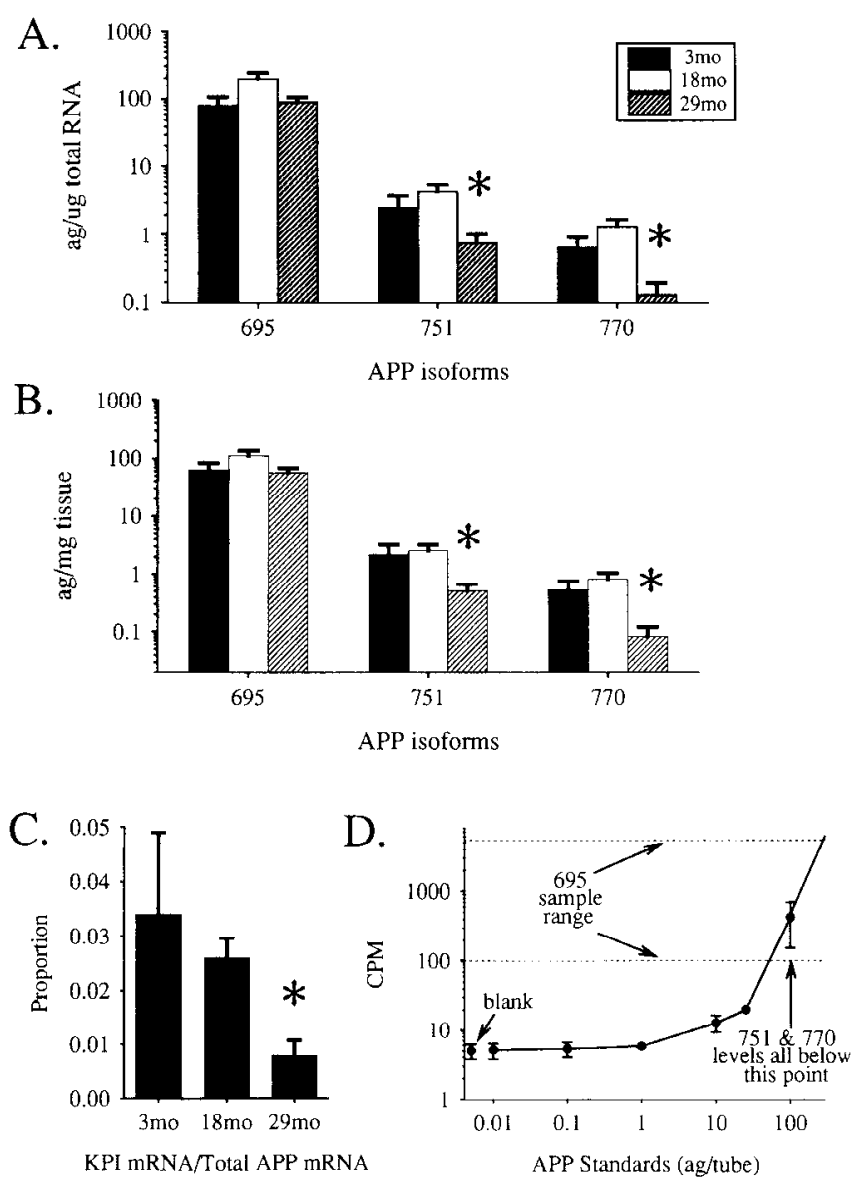

Figure 2. Extrapolated APP mRNA transcripts from right hippocampus. $A$, APP mRNA levels presented with respect to total RNA. $B$, APP mRNA levels presented in terms of milligrams of tissue. $C$, APP 751 and $770 \mathrm{mRNA}$ levels presented as percentage of total APP. $D$, Standard curve (note that APP 751 and 770 mRNA levels fall near the lower limit of sensitivity).

effects of age were evident in any of the other NGF or LNGFR measures, either for the main effects of age [all $F(2,59)<1.47$, $p$ values $>0.24]$, or for the contrasts between the 3 month and 18 month rats, and between 18 month and 29 month rats [all $F(1,59)<1.58, p$ values $>0.21]$.

\section{Reliability}

The detection and quantification of linear relationships between variables with the use of correlation/regression analyses, as planned in this study, are highly dependent on the ability to discriminate reliably between samples within each set of data. The degree to which samples could be discriminated was determined with the reliability coefficient, Cronbach's coefficient alpha (Nunnally, 1978; Cohen and Cohen, 1983; SAS Institute Inc., 1989). Rats could be reliably discriminated from one another in terms of their performance during acquisition of the spatial learning Morris water maze, and tissue samples could be reliably discriminated from one another with respect to all measures of NGF and LNGFR (Table 2).

The APP 695 mRNA levels among all rats $(n=62)$, and among the 18 month rats $(n=40)$, were sufficiently reliable to warrant correlational analyses (Table 2). The APP mRNA levels for the 751 and 770 forms, measured at less than 2 attograms (Fig. $2 D$ ), could not be reliably discriminated from one another 
Table 1. NGF and LNGFR levels (pg/mg tissuc)

\begin{tabular}{lccc}
$\begin{array}{l}\text { Area and } \\
\text { NGF/LNGFK }\end{array}$ & $\begin{array}{l}3 \text { month } \\
(n=5)\end{array}$ & $\begin{array}{l}18 \text { month } \\
(n=40)\end{array}$ & $\begin{array}{l}29 \text { month } \\
(n=17)\end{array}$ \\
\hline Cortical NGF & $5.45 \pm 4.77$ & $14.96 \pm 3.37$ & $2.77 \pm 0.695$ \\
Cortical LNGFR & $0.647 \pm 0.132$ & $0.639 \pm 0.070$ & $0.739 \pm 0.129$ \\
Hippocampal NGF & $1.47 \pm 0.27$ & $1.59 \pm 0.32$ & $2.16 \pm 0.66$ \\
Hippocampal LNGFR & $3.08 \pm 0.63$ & $2.30 \pm 0.20$ & $2.74 \pm 0.25$ \\
VDB LNGFR & $2.80 \pm 0.47$ & $3.02 \pm 0.22$ & $3.21 \pm 0.25$ \\
\hline
\end{tabular}

(Nunnally, 1978), which meant that they were not amenable to correlation/regression analyses. Therefore, \% KPI was used in this study for correlation/regression analyses, even though its reliability could not be precisely determined.

\section{Correlation/regression analyses}

\%KPI and APP 695 mRNA levels were significantly correlated with each other $[r(62)=0.43, p=0.0005]$. Except for cortical NGF levels, which were not significantly correlated with any other biological measure, all measures of NGF and LNGFR were significantly correlated with each other. LNGFR levels in the VDB were correlated with LNGFR levels in the cortex [ $r(62)$ $=0.46, p=0.0002]$, LNGFR levels in the hippocampus $[r(62)$ $=0.81, p=0.0001]$, and NGF levels in the hippocampus $[r(62)$ $=0.49, p=0.0001]$. LNGFR levels in the hippocampus were correlated with LNGFR levels in the cortex $[r(62)=0.36, p=$ $0.004]$ and NGF levels in the hippocampus $[r(62)=0.44, p-$ 0.0003 ]. Finally, hippocampal NGF levels were correlated with LNGFR levels in the cortex $[r(62)=0.86, p=0.0001]$.

Chronological age was correlated with acquisition swim distance $[r(62)=-0.44, p=0.0003]$, and there was a small but statistically significant correlation between \%KPI and acquisition swim distance among all rats $[r(62)=-0.27, p=0.03]$, and among the 18 month rats $[r(40)=-0.32, p=0.04]$. None of the other biological measures were significantly correlated with acquisition swim distance (Fig. 3). Furthermore, stepwise multiple regression analyses showed that, except for \%KPI, there was no statistically significant linear relationship between any combination of neurological variables and acquisition swim distance.

In order to determine whether nonlinear relationships might be present between the neurological and behavioral measures, an exploratory cluster analysis was performed post hoc, including all neurological measures and acquisition swim distance.

\begin{tabular}{|c|c|c|c|}
\hline Variable & $\begin{array}{l}\text { Total } \\
(n=62)\end{array}$ & $\begin{array}{l}18 \text { month } \\
(n=40)\end{array}$ & $\begin{array}{l}29 \text { month } \\
(n=17)\end{array}$ \\
\hline Maze acquisition & 0.77 & 0.67 & 0.77 \\
\hline APP 695 mRNA & 0.96 & 0.90 & 0.00 \\
\hline$\%$ KPI & NA & NA & NA \\
\hline Cortical LNGFR & 0.97 & 0.95 & 0.99 \\
\hline Cortical NGF & 0.98 & 0.98 & 0.94 \\
\hline Hippocampal NGF & 0.96 & 0.97 & 0.95 \\
\hline Hippocampal LNGFR & 0.98 & 0.99 & 0.96 \\
\hline VDB LNGFR & 0.95 & 0.95 & 0.95 \\
\hline
\end{tabular}

\footnotetext{
${ }^{a} r^{2}=$ proportion of variance accounted for.
}

The cluster analysis detected three natural groupings or clusters of subjects (Fig. 4): (1) rats that performed well in the water maze and had low levels of \%KPI and all measures of NGF and LNGFR ( $n=34)$, (2) rats that were mildly impaired in the spatial learning Morris water maze and had elevated levels of $\% \mathrm{KPI}$ and all measures of NGF and LNGFR $(n=8)$, and (3) rats that were more severely impaired in the spatial learning Morris water maze but had reduced levels of \% KPI, NGF, and LNGFR $(n=20)$. Except for the level of APP 695 mRNA, all biological variables included in this analysis had significant quadratic trends across these three groups or clusters of subjects: (1) $\% \mathrm{KPI}[F(1,59)=7.78, p=0.007]$, (2) cortical NGF $[F(1,59)$ $=3.80, p 0.05],(3)$ cortical LNGFR $[F(1,59)=58.62, p=$ $0.0001]$, (4) hippocampal NGF $[F(1,59)=72.28, p=0.0001]$, (5) hippocampal LNGFR $[F(1,59)=10.15, p=0.002]$, and $(6)$ VDB LNGFR $[F(1,59)=21.0, p=0.0001]$ (Fig. 4). Trend analysis on acquisition swim distance revealed significant linear $[F(1,59)=40.84, p=0.0001]$ but not quadratic trends across clusters.

\section{Discussion}

Cognitive function, as assessed with the spatial learning Morris water maze, generally declined progressively with chronological age from 3 months to 18 months, and from 18 months to 29 months. There was also a large range in performance between individuals, and even rats of the same age could be reliably discriminated from one another on the basis of their spatial learning ability. These individual differences seem ideal for determining the biological basis of senescence or physiological aging (as opposed to chronological aging) in cognitive function (Collier and Coleman, 1991; Fischer et al., 1992).

The RNA content in the tissue was significantly lower in 18 month rats relative to 3 month rats, which is consistent with age- and dementia-related decreases in overall rates of protein synthesis (Ekstrom et al., 1980; Fando et al., 1980; Davis et al., 1981; Davis and Squire, 1984; Marotta et al., 1986). However, there were no significant differences between 3 month and 18 month rats with respect to any of the neurochemical measures this study was designed to examine. In 29 month rats relative to 18 month rats, the levels of NGF in the cortex and KPIinclusive mRNA were reduced regardless of whether KPI-inclusive mRNA was presented with respect to total RNA, in terms of its concentration in the hippocampal tissue, or as a proportion of the total amount of APP mRNA. A statistically significant but small correlation was detected between \%KPI and spatial learning ability, with lower levels of \%KPI being related to more impaired spatial learning. No other statistically significant correlation or linear relationship could be detected between spatial learning ability and any of the other ncurological measures or any combination of these measures (i.e., hippo- 

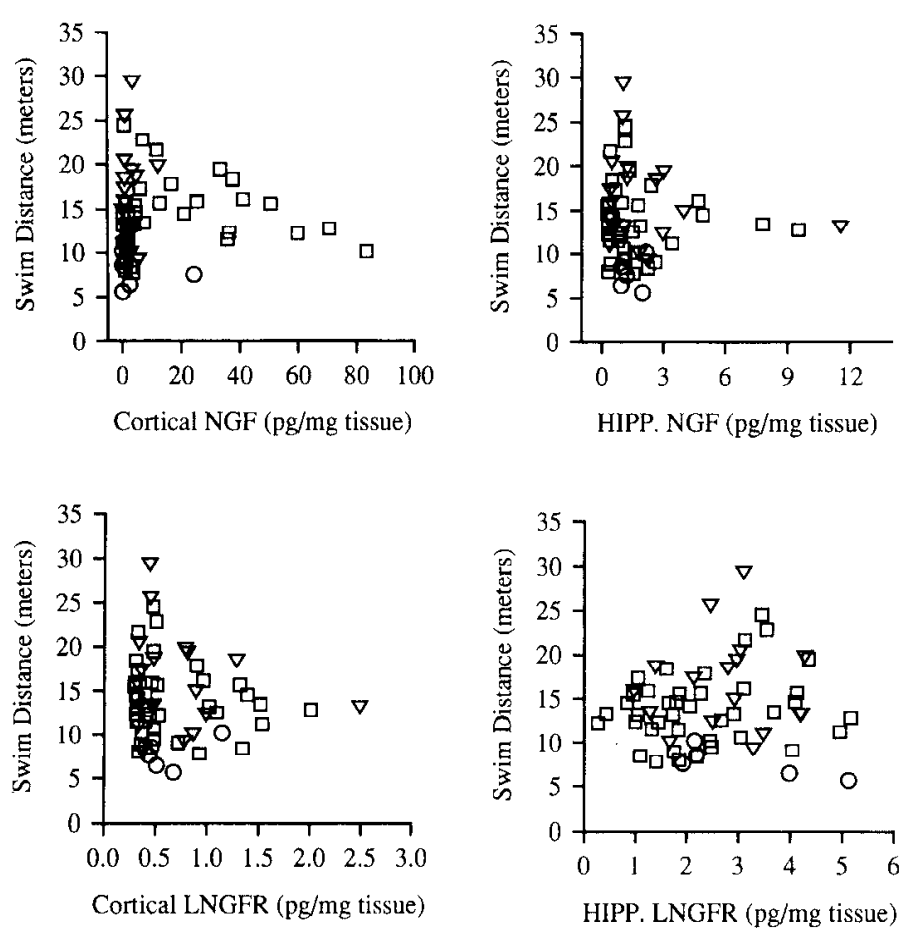

HIPP. LNGFR (pg/mg tissue)

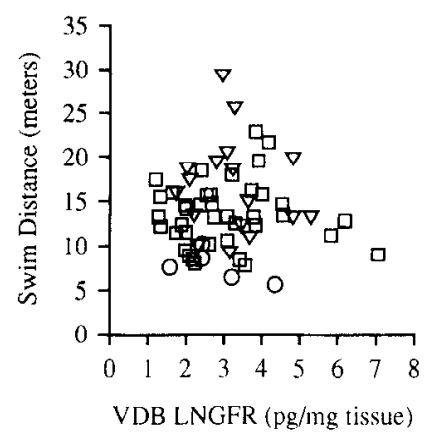

Figure 3. Scatter plots of acquisition swim distance with measures of NGF and LNGFR.

campal levels of APP 695 mRNA, cortical and hippocampal levels of NGF, and cortical, hippocampal, and basal forebrain levels of LNGFR).

It seems unlikely that large correlations between our neurological and behavioral measures went undetected because our data were invalid or unreliable. The validity of acquisition swim distance as a measure of cognitive function is supported by the facts that (1) age-related deficits were not detected in the cued version of the task, which is similar to the acquisition and probe trial tasks in terms of the noncognitive demands of the task (i.e., its dependence on motivation and its demands on motor and visual function), and (2) acquisition swim distances were correlated with several measures of performance in a probe trial. In addition, all data sets were highly reliable (i.e., swim distances, hippocampal levels of APP $695 \mathrm{mRNA}$, cortical and hippocampal levels of NGF, and cortical, hippocampal, and basal forebrain levels of LNGFR) with the exception of \%KPI (whose reliability could not be determined). It is conceivable that measures of cognitive function might be correlated with measures from brain areas not included in the present study (e.g., APP mRNA levels in cortex and NGF/LNGFR levels in nucleus basalis).

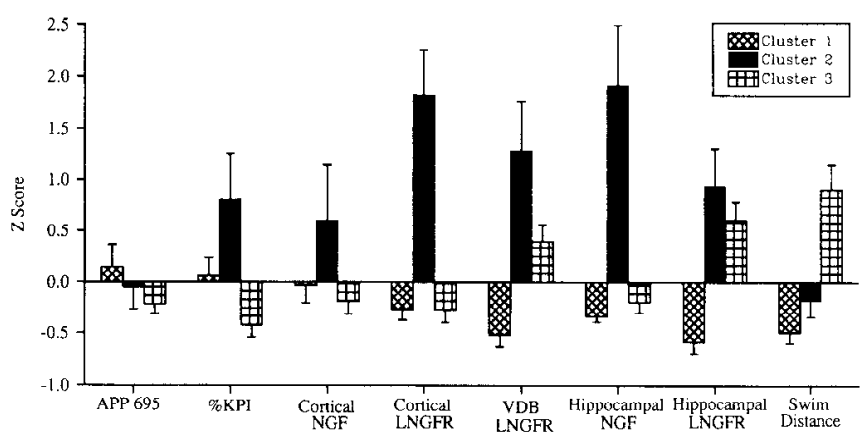

Figure 4. Bar chart showing results of cluster analysis. Note that spatial learning performance continuously declines from cluster 1 through cluster 3, but all biological measures except the APP 695 mRNA are low in cluster 1 , substantially elevated in cluster 2 , and lower again for cluster 3 (statistically significant quadratic trends).

Unfortunately, the present results do not help resolve the conflicting reports already present in the literature regarding APP mRNA changes as a function of age and cognitive ability. Jacobsen et al. (1991) and Palmert et al. (1988) reported that levels of APP $695 \mathrm{mRNA}$ are increased and levels of APP 751 and 770 mRNA are decreased in Alzheimer's patients compared to controls, but Robakis et al. (1991) did not detect APP 751 mRNA in rats and concluded that KPI-inclusive forms of APP mRNA may be related to plaque formation in humans, and Tanaka et al. (1992) reported that APP 770 and 751 mRNAs were increased relative to the amount of APP 695 mRNA in Alzheimer's patients. Higgins et al. (1990) reported that learning-impaired aged rats have increased levels of KPI-containing APP mRNA, but Greene et al. (1992) reported increased levels of APP 695 mRNA in learning-impaired aged rats.

Published studies of the relationship between NGF and cognitive function are, likewise, in conflict. Henriksson et al. (1992) reported that learning-impaired aged rats have lower levels of hippocampal NGF, but Hellweg et al. (1990) reported that cortical NGF levels were higher in learning-impaired aged rats. Goedert et al. (1986) reported no difference in temporal/parietal NGF mRNA levels in Alzheimer's patients, and Allen et al. (1991) reported no difference in hippocampal or cortical NGF levels in Alzheimer's patients. On the other hand, Crutcher et al. (1993) reported an incrcasc in cortical NGF levels in Alzheimer's patients, and in our lab (R. Loy, M. D. Lindner, and R. W. Hamill, 1993 unpublished observations) we find a decrease in cortical NGF and LNGFR levels in Alzheimer's patients.

To our knowledge, this is the first study quantifying tissue levels of LNGFR. It seems surprising that tissue levels of LNGFR do not decline markedly as cognitive function deteriorates since morphological measures of the degeneration of ChAT/LNGFRpositive neurons are consistently related to the degree of cognitive dysfunction (Fischer et al., 1989, 1992; Koh et al., 1989). However, there is some evidence that LNGFR production increases, at least during the initial period of LNGFR-positive neuronal degeneration (Lindner et al., 1993), and a combination of increasing LNGFR production per neuron with decreasing numbers of LNGFR-positive neurons could explain why tissue levels of LNGFR are not linearly related to behavioral measures of cognitive dysfunction in the present study.

There is also some evidence that transient increases in tissue levels of NGF may occur during the initial period of cognitive 
deterioration (Hellweg et al., 1990), and the post hoc cluster analysis conducted in the present study supports the possibility that tissue levels of \%KPI, NGF, and LNGFR may all exhibit transient increases during the initial period of cognitive deterioration, perhaps before substantial neuronal degeneration has occurred. To test this possibility, future studies could independently quantify tissue levels of neurochemical measures and the number of neurons producing these substances. In addition, since transient increases in levels of NGF (Needels et al., 1985; Nieto-Sampedro and Cotman, 1985; Gasser et al., 1986; Hengerer et al., 1990; Ballarin et al., 1991), LNGFR mRNA (Brunello et al., 1990), APP and APP mRNA levels have been observed following neuronal injury (Otsuka et al., 1991; Scott et al., 1991; Wallace et al., 1991; Shigematsu and McGeer, 1992), studies could test the possibility that an early critical period of neuronal vulnerability may occur during physiological aging and cognitive decline.

\section{References}

Allen SJ, MacGowan SH, Treanor JJ, Feeney R, Wilcock GK, Dawbarn D (1991) Normal $\beta$-NGF content in Alzheimer's disease cerebral cortex and hippocampus. Neurosci Lett 131:135 139.

Appel SH (1981) A unifying hypothesis for the cause of amyotrophic lateral sclerosis, parkinsonism, and Alzheimer disease. Ann Neurol 10:499-505.

Ballarin M, Ernfors P, Lindefors N, Persson H (1991) Hippocampal damage and kainic acid injection induce a rapid increase in mRNA for BDNF and NGF in the rat brain. Exp Neurol 1 14:35-43.

Blessed G, Tomlinson BE, Roth M (1968) The association between quantitative measures of dementia and of senile change in the cerebral grey matter of elderly subjects. Br J Psychiatry 114:797-811.

Brunello N, Reynolds M, Wrathall JR, Mocchetti I (1990) Increased nerve growth factor receptor mRNA in contused rat spinal cord. Neurosci Lett 118:238-240.

Chomczynski P, Sacchi N (1987) Single-step method of RNA isolation by acid guanidinium thiocyanate-phenol-chloroform extraction. Anal Biochem 162:156-159.

Cohen J, Cohen P (1983) Applied multiple regression/correlation analysis for the behavioral sciences. Hillsdale, NJ: Erlbaum.

Collier TJ, Coleman PD (1991) Divergence of biological and chronological aging: evidence from rodent studies. Neurobiol Aging 12: 685-693.

Crutcher KA, Scott SA, Liang S, Everson WV, Weingartner J (1993) Detection of NGF-like activity in human brain tissue: increased levels in Alzheimer's disease. J Neurosci 13:2540-2550.

Davis HP, Squire LR (1984) Protein synthesis and memory: a review. Psychol Bull 96:518-559.

Davis HP, Rosenzweig MR, Kinkade PT, Bennett EL (1981) Effects of anisomycin on retention of the passive avoidance habit as a function of age. Exp Aging Res 7:33-44.

Dodd DH, Schultz RF Jr (1973) Computational procedures for estimating magnitude of effect for some analysis of variance designs. Psychol Bull 79:391-395.

Ekstrom R, Liu DSH, Richardson A (1980) Changes in brain protein synthesis during the life span of male Fischer rats. Gerontology 26: $121-128$

Fando JL, Salinas M, Wasterlain CG (1980) Age-dependent changes in brain protein synthesis in the rat. Neurochem Res 5:373-383.

Fischer W, Gage FH, Bjorklund A (1989) Degenerative changes in forebrain cholinergic nuclei correlate with cognitive impairments in aged rats. Eur J Neurosei 1:34-45.

Fischer W, Chen KS, Gage FH, Bjorklund A (1992) Progressive decline in spatial learning and integrity of forebrain cholinergic neurons in rats during aging. Neurobiol Aging 13:9-23.

Fisher RA (1934) Statistical methods for research workers. Edinburgh: Oliver and Boyd.

Gasser UE, Weskamp G, Otten U, Dravid AR (1986) Time coursc of the elevation of nerve growth factor (NGF) content in the hippocampus and septum following lesions of the septohippocampal pathway in rats. Brain Res 376:351-356.
Gilliland G, Perrin S, Blanchard K, Bunn HF (1990) Analysis of cytokine mRNA and DNA: detection and yuantitation by competitive polymerase chain reaction. Proc Natl Acad Sci USA 87:27252729.

Goedert M, Fine A, Hunt SP, Ullrich A (1986) Nerve growth factor mRNA in peripheral and central rat tissues and in the human central nervous system: lesion effects in the rat brain and levels in Alzheimer's disease. Mol Brain Res 1:85-92.

Greene RM, Robbins MD, Gallagher M, McKinney M (1992) Measuring changes in transcript levels for various genes in the medial septum and hippocampus of rats due to age and memory impairment. Soc Neurosci Abstr 18:1481.

Harrison PJ, Barton AJ, Pearson RC (1991) Expression of amyloid beta-protein precursor mRNAs in familial Alzheimer's disease. Neuroreport 2:152-154.

Hellweg R, Fischer W, Hock C, Gage FH, Bjorklund A, Thoenen H (1990) Nerve growth factor levels and choline acetyltransferase activity in the brain of aged rats with spatial memory impairments. Brain Kes 537:123-130.

Hengerer B, Lindholm D, Heumann R, Ruther U, Wagner EF, Thoenen $H$ (1990) Lesion-induced increase in nerve growth factor mRNA is mediated by c-fos. Proc Natl Acad Sci USA 87:3899-3903.

Henriksson BG, Soderstrom S, Gower AJ, Ebendal T, Winblad B, Mohammed $\mathrm{AH}$ (1992) Hippocampal nerve growth factor levels are related to spatial learning ability in aged rats. Behav Brain Res 48: 15-20.

Higgins GA, Mufson EJ (1989) NGF receptor gene expression is decreased in the nucleus basalis in Alzheimer's disease. Exp Neurol 106 : 222-236.

Higgins GA, Oyler GA, Neve RL, Chen KS, Gage FH (1990) Altered levels of amyloid protein precursor transcripts in the basal forebrain of behaviorally impaired aged rats. Proc Natl Acad Sci USA 87:30323036.

Jacobsen JS, Blume AJ, Vitek MP (1991) Quantitative measurement of alternatively spliced amyloid precursor protein mRNA expression in Alzheimer's disease and normal brain by $\mathrm{S} 1$ nuclease protection analysis. Neurobiol Aging 12:585-592.

Koh S, Chang P, Collier TJ, Loy R (1989) Loss of NGF receptor immunoreactivity in basal forebrain neurons of aged rats: correlation with spatial memory impairment. Brain Res 498:397-404.

Kordower JH, Gash DM, Bothwell M, Hersh L, Mufson EJ (1989) Nerve growth factor receptor and choline acetyltransferase remain colocalized in the nucleus basalis (Ch4) of Alzheimer's patients. Neurobiol Aging 10:67-74.

Kozlowski MR, Spanoyannis A, Manly SP, Fidel SA, Neve RL (1992) The neurotoxic carboxy-terminal fragment of the Alzheimer amyloid precursor binds specifically to a neuronal cell surface molecule: $\mathrm{pH}$ dependence of the neurotoxicity and the binding. J Neurosci 12:16791687.

Lindner MD, Gribkoff VK (1991) Relationship between performance in the Morris water task, visual acuity, and thermoregulatory function in aged F-344 rats. Behav Brain Res 45:45-55.

Lindner MD, Schallert T (1988) Aging and atropine effects on spatial navigation in the Morris water task. Behav Neurosci 102:621-634.

Lindner MD, Balch AH, VanderMaelen CP (1992) Short forms of the "reference-" and "working-memory" Morris water maze for assessing age-related deficits. Behav Neural Biol 58:94-102.

Lindner MD, Gordon DD, Miller JM, Tariot PN, McDaniel KD, Hamill RW, DiStefano PS, Loy R (1993) Increased levels of truncated NGF receptor in urine of mildly demented patients with Alzheimer's disease. Arch Neurol 50:1054-1058.

Loy R, Heyer D, Clagett-Dame M, DiStefano PS (1990) Localization of NGF receptors in normal and Alzheimer's basal forebrain with monoclonal antibodies against the truncated form of the receptor. $J$ Neurosci Res 27:651-664.

Marotta CA, Majocha RE, Coughlin JF, Manz HJ, Davies P, VentosaMichelman M, Chou W-G, Zain SB, Sajdel-Sulkowska EM (1986) Transcriptional and translational regulatory mechanisms during normal aging of the mammalian brain and in Alzheimer's disease. Prog Brain Res 70:303-320.

McGeer PL, McGeer EG, Suzuki J, Dolman CE, Nagai T (1984) Aging, Alzhcimer's discase, and the cholinergic system of the basal forebrain. Neurology 34:741-745.

Milward EA, Papadopoulos R, Fuller SJ, Moir RD, Small D, Beyreuther K, Masters CL (1992) The amyloid protein precursor of Alzheimer's 
disease is a mediator of the effects of nerve growth factor on neurite outgrowth. Neuron 9:129-137.

Mobley WC, Rutkowski JL, Tennekoon GI, Gemski J, Buchanan K, Johnston MV (1986) Nerve growth factor increases choline acetyltransferase activity in developing basal forebrain neurons. Mol Brain Res 1:53-62.

Mobley WC, Woo JE, Edwards RH, Riopelle RJ, Longo FM, Weskamp G, Otten U, Valletta JS, Johnston MV (1989) Developmental regulation of nerve growth factor and its receptor in the rat caudateputamcn. Ncuron 3:655-664.

Morris R (1984) Developments of a water-maze procedure for studying spatial learning in the rat. J Neurosci Methods 11:47-60.

Mufson EJ, Kordower JH (1989) Nerve growth factor receptor expressing human basal forebrain neurons: pathologic alterations in Alzheimer's and Parkinson's disease. Prog Clin Biol Res 317:401414

Mufson EJ, Bothwell M, Hersh LB, Kordower JH (1989a) Nerve growth factor receptor immunoreactive profiles in the normal, aged human basal forebrain: colocalization with cholinergic neurons. J Comp Neurol 285:196-217.

Mufson EJ, Bothwell M, Kordower JH (1989b) Loss of nerve growth factor receptor-containing neurons in Alzheimer's disease: a quantitative analysis across subregions of the basal forebrain. Exp Neurol 105:221-232.

Needels DL, Nieto-Sampedro M, Whittemore SR, Cotman CW (1985) Neuronotrophic activity for ciliary ganglion neurons. Induction following injury to the brain of neonatal, adult, and aged rats. Brain Res 350:275-284.

Nieto-Sampedro M, Cotman CW (1985) Growth factor induction and temporal order in central nervous system repair. In: Synaptic plasticity (Cotman CW, ed), pp 407-455. New York: Guilford.

Nunnally JC (1978) Psychometric theory. New York: McGraw-Hill.

Otsuka N, Tomonaga M, Ikeda K (1991) Rapid appearance of betaamyloid precursor protein immunoreactivity in damaged axons and reactive glial cells in rat brain following needle stab injury. Brain Res 568:335-338.

Palmert MR, Golde TE, Cohen ML, Kovacs DM, Tanzi RE, Gusella JF, Usiak MF, Younkin LH, Younkin SG (1988) Amyloid protein precursor messenger RNAs: differential expression in Alzheimer's disease. Science 241:1080-1084.

Paxinos G, Watson C (1986) The rat brain in stereotaxic coordinates. Orlando, FL: Academic.

Plikaytis BD, Turner SH, Gheesling LL, Carlone GM (1991) Comparisons of standard curve-fitting methods to quantitate Neisseria meningitis group A polysaccharide antibody levels by enzyme-linked immunosorbent assay. J Clin Microbiol 29:1439-1446.
Robakis NK, Anderson JP, Refolo LM, Wallace W (1991) Expression of the Alzheimer amyloid precursor in brain tissue and effects of NGF and EGF on its metabolism. Clin Neuropharmacol 14[Suppl 1]:S15S23.

Rodbard D, McClean SW (1977) Automated computer analysis for enzyme-multiplied immunological techniques. Clin Chem 23:112115.

Roth M, Tomlinson BE, Blessed G (1966) Correlation between scores for dementia and counts of "senile plaques" in cerebral grey matter of elderly subjects. Nature 209:109-1 10.

SAS Institute Inc. (1989) SAS/STAT user's guide, version 6, 4th ed, Vol 1. Cary, NC: SAS Institute Inc.

Scott JN, Parhad IM, Clark AW (1991) Beta-amyloid precursor protein gene is differentially expressed in axotomized sensory and motor systems. Brain Res Mol Brain Res 10:315-325.

Shigematsu K, McGeer PL (1992) Accumulation of amyloid precursor protein in neurons after intraventricular injection of colchicine. Am J Pathol 140:787-794.

Smith CJ, Wion D, Brachet P (1991) Nerve growth factor-induced neuronal differentiation is accompanied by differential splicing of beta-amyloid precursor mRNAs in the PC12 cell line. Brain Res Mol Brain Res 10:351-354.

Tanaka S, Liu L, Kimura J, Shiojiri S, Takahashi Y, Kitaguchi N, Nakamura S, Ueda K (1992) Age-related changes in the proportion of amyloid precursor protein mRNAs in Alzheimer's disease and other neurological disorders. Brain Res Mol Brain Res 15:303-310.

Wallace WC, Bragin V, Robakis NK, Sambamurti K, VanderPutten D, Merril CR, Davis KL, Santucci AC, Haroutunian V (1991) Increased biosynthesis of Alzheimer amyloid precursor protein in the cerebral cortex of rats with lesions of the nucleus basalis of Meynert. Mol Brain Res 10:173-178.

Weskamp G, Otten $U$ (1987) An enzyme-linked immunoassay for nerve growth factor (NGF): a tool for studying regulatory mechanisms involved in NGF production in brain and in peripheral tissues. J Neurochem 48:1779-1786.

Weskamp G, Reichardt LF (1991) Evidence that biological activity of NGF is mediated through a novel subclass of high affinity receptors. Ncuron 6:649-663.

Whitehouse PJ, Price DL, Clark AW, Coyle JT, DeLong MR (1981) Alzheimer disease: evidence for selective loss of cholinergic neurons in the nucleus basalis. Ann Neurol 10:122-126.

Yankner BA, Caceres A, Duffy LK (1990) Nerve growth factor potentiates the neurotoxicity of amyloid. Proc Natl Acad Sci USA 87: 9020-9023. 